\title{
Reproductive biotechnologies
}

\section{IN VITRO PRODUCTION OF INTERSPECIES HYBRID EMBRYOS OF CATTLE (Bos taurus) AND WISENT (Bison bonasus)}

\section{G.N. SINGINA, V.A. BAGIROV, S.S. DANCH, T.E. TARADAINIK, A.V. DOTSEV, N.A. ZINOVIEVA}

L.K. Ernst All-Russian Research Institute of Animal Husbandry, Federal Agency of Scientific Organizations, 60, pos. Dubrovitsy, Podolsk District, Moscow Province, 142132 Russia, e-mail g_singina@mail.ru Acknowledgements

Supported by the Program of Presidium of the Russian Academy of Science (project No IV.13.3)

Received September 28, 2016

\section{Abstract}

European bison or wisent (Bison bonasus) is a rare species that is endangered. The technology for producing in vitro embryos using oocytes of cows and wisent semen can be an effective tool for conservation of genetic resources of this species and their rational use in basic research on the physiology of development and to create the new animals' types. However, the methods for production of in vitro embryos using the above-mentioned germ cells are currently not described in the literature. In this work, we first attempted to obtain the hybrid cow-wisent embryos in vitro using the IVM/IVF/IVC protocol, developed for domestic cattle (Bos taurus). Frozen epididymal sperm derived from wisent was thawed and prepared by the swim-up procedure. Matured oocytes were coincubated during $18 \mathrm{~h}$ together with prepared sperm in Fert-Talp medium, which was replaced then by embrional medium where the embryos were cultured until the blastocyst state. Additionally, for positive control, a part of matured bovine oocytes were fertilized with frozen/thawed ejaculated bull sperm. Fertilizing capacity of male cells of both species was assessed according to the nature of spermatozoa-egg interactions, as well as the capacity of fertilized bovine oocytes to subsequent embryonic development. It was found that the rate of oocytes with sing polyspermy was higher for fertilization with wisent sperm comparing to allogenic insemination $(21.6$ vs. $8.5 \%, \mathrm{P}<0.05)$. There were no differences between two types of fertilizations nether for the sperm penetration rate ( $90.0 \pm 0.3$ vs. $93.3 \pm 1.7 \%$ for bull and wisent, respectively), nor for the rate of normal fertilization $(78.3 \pm 1.7 \%$ vs. $73.2 \pm 2.3 \%)$. The similar cleavage and blastocyst formation rates were observed for two fertilization types. Our data indicate the similarity in the mechanisms of oocyte activation and embryonic development in cow and wisent females. In addition, it is obvious that IVM/IVF/IVP protocol, in general, allows in vitro producing cattle-wisent hybrid embryos, however, high levels of polyspermy observed in heterogeneous fertilization, indicates the necessity to adjust the method.

Keywords: cattle oocytes, the European bison sperm, fertilization in vitro, hybrid embryos

European bison, or wisent, (Bison bonasus) is a rare endangered species. Current European bison population is strongly inbred. All modern wisents come from 12 individuals kept in the zoos and reserves in the early XX century [1]. Low genetic variability is one of the main threats to the long-term maintenance of the species. Assisted reproductive technology such as production of in vitro embryos using oocytes of domestic cattle and wisent semen will not only help to maintain the existing genetic resources of the species, but also to involve this species in basic research on the physiology of development and use in creations of new bred forms [2-4].

Cow oocytes are a universal object for interspecific hybridization. In publications, there is evidence of their in vitro fertilization using semen of gaur [5], antelope [6], horse [7], sheep [8], and donkey [9]. Close relationship between the species, the lack of specific antigens against wisent spermatozoa in the pellucid zone (PZ) of cow oocytes [10], and the previously described possibility to obtain a hybrid offspring by crossing [11] are the prerequisites for extracorpo- 
real hybridization between bovine oocytes and wisent sperm.

Current development of in vitro technologies makes the efficient and large-scale obtaining of the embryos of domestic animals possible [12-16]. However, the biological usefulness of oocytes reduces during further embryonic development with interspecific extracorporeal fertilization (even with closely related species) [17]. One solution to the problem is adjustment of the method depending on the specificity of source gametes and embryos.

Typically, the schemes developed for domestic animals are used for extracorporeal hybridization involving the gametes of rare and wild species as basic IVM (in vitro maturation)/IVF (in vitro fertilization)/IVC (in vitro culture) protocols [17-19]. Own technology for producing embryos in vitro for wisent has not been modeled yet. Cases of Bos taurus and Bison bonasus hybrids under similar conditions have not been described in publications as well.

In this paper, a possibility of formation and development of interspecific hybrids resulting from in vitro fertilization of cow oocytes by wisent sperm until the blastocyst stage is demonstrated for the first time.

The purpose of the study was fertilization of bovine oocytes by wisent sperm and evaluation of their further embryonic development in vitro using a protocol routinely used in vitro for domestic cattle embryos.

Technique. The source of females germ cells were cow ovaries collected after slaughter and delivered to the laboratory within 2-3 hours at $30-35{ }^{\circ} \mathrm{C}$.

Oocyte-cumulus complexes (OCC) were isolated by dissecting visible follicles and washing 3 times in TC-199 medium containing $5 \%$ fetal bovine serum, $10 \mu \mathrm{g} / \mathrm{ml}$ heparin, $0.2 \mathrm{mM}$ sodium pyruvate, and $50 \mu \mathrm{g} / \mathrm{ml}$ gentamicin (Sigma, USA). Round shape oocytes with homogeneous cytoplasm and uniform width pellucid area surrounded by compact cumulus were collected for the experiments. OCC were cultured in groups of 25-35 oocytes in $500 \mu 1$ of modified TC199 medium [20] under a layer of light mineral oil (Sigma, USA) for 24 hours. The matures oocyte was transferred to Fert-TALP fertilization medium containing $114 \mathrm{mM} \mathrm{NaCl}, 3.2 \mathrm{mM} \mathrm{KCl}, \quad 0.4 \quad \mathrm{mM} \quad \mathrm{NaH}_{2} \mathrm{PO}_{4} \times 2 \mathrm{H}_{2} \mathrm{O}, 2 \mathrm{mM}$ $\mathrm{CaCl}_{2} \times 2 \mathrm{H}_{2} \mathrm{O}, 0.5 \mathrm{mM} \mathrm{MgCl}{ }_{2} \times 6 \mathrm{H}_{2} \mathrm{O}, 25 \mathrm{mM} \mathrm{NaHCO}, 10 \mathrm{mM}$ HEPES, $10 \mathrm{mM}$ sodium lactate, $0.25 \mathrm{mM}$ sodium pyruvate, $6 \mathrm{mg} / \mathrm{ml}$ bovine serum albumin (BSA), $10 \mu \mathrm{g} / \mathrm{ml}$ heparin, $20 \mu \mathrm{M}$ penicillamine, $10 \mu \mathrm{M}$ hypotaurine, $1 \mu \mathrm{M}$ epinephrine, $0.1 \%$ nonessential amino acids and $50 \mu \mathrm{g} / \mathrm{ml}$ gentamicin (Sigma, USA).

Frozen epididymal semen obtained after the forced shooting of 7 year old wisents was used for fertilization ( $q$ cow $-\delta$ wisent fertilization). Bovine semen was the positive control ( $q$ cow $-\lambda$ bull fertilization). Before the procedure, sperm was thawed for $1 \mathrm{~min}$ at $37^{\circ} \mathrm{C}$ and prepared by swim-up procedure [21] using Sperm-TALP medium containing $100 \mathrm{mM} \mathrm{NaCl}, 3.1 \mathrm{mM} \mathrm{KC1}, 0.3$ $\mathrm{mM} \mathrm{NaH}{ }_{2} \mathrm{PO}_{4} \cdot 2 \mathrm{H}_{2} \mathrm{O}, 2 \mathrm{mM} \mathrm{CaCl} \cdot 2 \mathrm{H}_{2} \mathrm{O}, 1.5 \mathrm{mM} \mathrm{MgCl} 2 \cdot 6 \mathrm{H}_{2} \mathrm{O}, 25 \mathrm{mM}$ $\mathrm{NaHCO}_{3}, 10 \mathrm{mM}$ HEPES, $21.6 \mathrm{mM}$ sodium lactate, $1 \mathrm{mM}$ sodium pyruvate, $6 \mathrm{mg} / \mathrm{ml} \mathrm{BSA} \mathrm{(Sigma,} \mathrm{USA).} \mathrm{The} \mathrm{resulting} \mathrm{active} \mathrm{spermatozoa} \mathrm{fraction} \mathrm{was} \mathrm{add-}$ ed to the dishes with Fert-TALP medium and mature oocytes at a dose of $1.0 \times 10^{6}$ spermatozoa $/ \mathrm{ml}$.

After 18-20 hours of co-culture, cumulus cells and the adhered sperm cells were removed from oocytes, then part of the oocytes was used for the cytological analysis of penetration and fertilization rates. The remaining oocytes were transferred to specialized medium [22] and cultured until day 7. The oocyte cleavage and blastocyst formation rates were determined.

For the cytogenetic studies of the nuclei of inseminated oocytes, they were fixed in $4 \%$ paraformaldehyde, subjected to permeabilization in $0.5 \%$ Triton X-100 solution, stained with $1 \mu \mathrm{g} / \mathrm{ml}$ DAPI (Sigma, USA), then transferred to a degreased glass slide and embedded in Vectashield medium (Vector Labora- 
tories, UK). Cytological preparations were examined using fluorescence light microscopy (Axiovert 40 CFL microscope, Carl Zeiss, Germany) at a $\times 40$ magnification.

When calculating penetration rate, the presence of condensed sperm heads and male pronuclei in the cytoplasm of mature oocytes were counted. The oocytes with male and female pronuclei, or condensed sperm heads, as well as the ones in anaphase II or telophase II were considered the cells with normal fertilization. In addition, oocytes that contain two or more condensed sperm heads in the cytoplasm and two or more male pronuclei were defined as the oocytes with polyspermic fertilization.

OCC maturation and fertilization were carried out, and embryo cultures were maintained in $5 \% \mathrm{CO}_{2}$ atmosphere at a temperature of $38.5{ }^{\circ} \mathrm{C}$ and $90 \%$ humidity.

Experiments on OCC culture were performed in 3-4 independent replicates. The data were processed by ANOVA using SigmaStat software (IBM SPSS, USA). The significance of differences of the mean values compared was assessed using Tukey test. Percentages $(X)$ and the error of the mean $(m)$ are provided.

Results. Domestic cattle (Bos taurus) is the leader in the efficient and large-scale obtaining of embryos in vitro. There is evidence of extracorporeal fertilization of bovine oocytes by the semen of different species [6-9], including closely related ones: gaur (Bos gaurus), banteng (B. javanicus) [5], yak (B. grunniens) [5, 18], African (Syncerus caffer caffer) and Asian (Bubalus bubalis) buffalo [17, 19], and American bison (Bison bison) [23].

Analysis of the data obtained in this study (Table 1) demonstrated an increase in the proportion of oocytes with polyspermy at interspecific fertilization (by $13.1 \%, \mathrm{P}<0.05$ ) as compared to intraspecific fertilization, but did not reveal any differences between the two types of fertilization neither in the proportion of oocytes with manifestations of sperm penetration through pellucid zone, nor in the proportion of normally fertilized oocytes. According to the published data, polyspermy is observed in 8-55\% at IVF in cows, depending on the individual characteristics of the bull, sperm concentration and conditions of capacitation and fertilization [24, 25].

As in most other studies, to obtain interspecific hybrid embryos, we used the technological system used in extracorporeal fertilization in cattle [26]. As in the case of bovine oocytes contact with bull sperm a polyspermy was lower than when they interacted with wisent sperm, it can be assumed that a too high concentration of male gametes was used for interspecific fertilization, or the conditions for the interaction of male and female cells proved inadequate. It is worth noting that similar results were observed when bovine oocytes were in vitro fertilized by yak semen [18].

1. Extracorporeal fertilization of cow (Bos taurus) oocytes by frozen-thawed bull and wisent (Bison bonasus) epididymal semen $(X \pm m)$

\begin{tabular}{|c|c|c|c|c|c|}
\hline \multirow[b]{2}{*}{ Fertilization } & \multirow{2}{*}{$\begin{array}{l}\text { Number of } \\
\text { experiments }\end{array}$} & \multirow{2}{*}{$\begin{array}{l}\text { Inseminated } \\
\text { oocytes, } n\end{array}$} & \multicolumn{3}{|c|}{ Proportion of oocytes, $\%$} \\
\hline & & & with penetration & $\begin{array}{l}\text { with normal } \\
\text { fertilization }\end{array}$ & $\begin{array}{l}\text { with polyspermic } \\
\text { fertilization }\end{array}$ \\
\hline qcow- & 3 & 77 & $90.0 \pm 0.3$ & $78.3 \pm 1.7$ & $8.5 \pm 1.8^{\mathrm{a}}$ \\
\hline qcow-Ôwisent & 3 & 81 & $93.3 \pm 1.7$ & $73.2 \pm 2.3$ & $21.6 \pm 0.8^{b}$ \\
\hline
\end{tabular}

In an earlier study, heterogeneous fertilization of bovine oocytes was used to assess the European bison sperm fertility. The effectiveness of insemination was determined by the penetration of sperm through the oocyte PZ and pronuclei formation [10]. However, embryo formation and development is the 
best evidence of successful gamete interaction.

In our experiments, the oocyte cleavage and blastocyst formation rates after insemination of bovine oocytes by wisent sperm were high and did not differ from those after bull sperm fertilization (Table 2). Moreover, in both cases, parameters of embryonic development were consistent with the traditional values resulting from IVF in cattle $[13,26]$.

2. Early embryonic development of bovine (Bos taurus) oocytes after in vitro fertilization by frozen-thawed wisent (Bison bonasus) epididymal semen $(X \pm m)$

\begin{tabular}{|c|c|c|c|c|c|}
\hline \multirow[t]{2}{*}{ Fertilization } & \multirow{2}{*}{$\begin{array}{l}\text { Number of } \\
\text { experiments }\end{array}$} & \multirow{2}{*}{$\begin{array}{l}\text { Inseminated } \\
\text { oocytes, } n\end{array}$} & \multirow{2}{*}{$\begin{array}{l}\text { Oocyte cleavage } \\
\text { rate, } \%\end{array}$} & \multicolumn{2}{|c|}{$\begin{array}{l}\text { Proportion of oocytes developed } \\
\text { to the blastocyst stage, } \%\end{array}$} \\
\hline & & & & of inseminated & of cleavaged \\
\hline +cow- bull & 4 & 143 & $72.4 \pm 2.5$ & $26.7 \pm 1.9$ & $37.1 \pm 2.6$ \\
\hline +cow- & 4 & 131 & $77.1 \pm 2.5$ & $27.8 \pm 3.5$ & $35.8 \pm 3.3$ \\
\hline
\end{tabular}

Our findings and the results of other studies [10] suggest that wisent male gametes are capable of recognizing specific carbohydrate sequence of bovine oocyte pellucid zone glycoprotein and overcome the species barrier, and the acrosome enzymes contribute to sperm penetration into xenogenous oocytes. In addition, the fact of two-cell hybrid embryos formation and their development to the blastocyst stage indicates the similarity in the mechanisms of oocyte activation and embryonic development in cow and wisent females.

Thus, bovine oocytes can be fertilized by wisent sperm, and the resulting interspecies zygotes are capable of forming pre-implantation embryos. It is also obvious that IVM/IVF/IVP protocol, in general, allows in vitro producing cattle-wisent hybrid embryos, but the high levels of polyspermy observed in heterogeneous fertilization indicate the necessity to adjust the method.

\section{REFEREN C ES}

1. O le c h W. Analysis of inbreeding in European bison. Acta Theriologica, 1987, 32: 373-387.

2. Kozdrowski R., Niżański W., Dubi el A., O le ch W. Possibilities of using the European bison (Bison bonasus) epididymal spermatozoa collected post-mortem for cryopreservation and artificial insemination: a pilot study. Reprod. Biol. Endocrinol., 2011, 9(1): 31 (doi: 10.1186/1477-7827-9-31).

3. Khandoker M.A.M.Y., Reza M.M.T., Asad L.Y., Saha S., Apu A.S., Hoqu e S.A.M. In vitro maturation of buffalo oocytes and fertilization by cattle spermatozoa. Bang. J. Anim. Sci., 2012, 41(1): 6-12 (doi: 10.3329/bjas.v41i1.11969).

4. Singina G.N., Volkova N.A., Bagirov V.A., Zi novi eva N.A. Cryobanking of somatic cells in conservation of animal genetic resources: prospects and successes (review). Agricultural Biology, 2014, 6: 3-14 (doi: 10.15389/agrobiology.2014.6.3eng) (in Engl.).

5. M c Hugh J.A., Rut le d ge J.J. Heterologous fertilization to characterize spermatozoa of the genus Bos. Theriogenology, 1998, 50(2): 185-193 (doi: 10.1016/S0093-691X(98)00125-3).

6. Kouba A.J., Atkinson M.W., Gandolf A.R., Roth T.L. Species-specific sperm-egg interaction affects the utility of a heterologous bovine in vitro fertilization system for evaluating antelope sperm. Biol. Reprod., 2001, 65(4): 1246-1251 (doi: 10.1095/biolreprod65.4.1246).

7. Campos-Chillun L.F., B arcelo-Fimbres M., Carnevale E.M., Seide 1 G.E.J. Use of bovine oocytes to evaluate in vitro fertilizing capacity of equine sperm. Theriogenology, 2007, 68(3): 515-516 (doi: 10.1016/j.theriogenology.2007.05.036).

8. Garcia-Alvarez O., Maroto-Morales A., Martínez-Pastor F., Ferná nd e z-S a n tos M.R., Es te so M.C., Pérez-Guz mán M.D., S o le r A.J. Heterologous in vitro fertilization is a good procedure to assess the fertility of thawed ram spermatozoa. Theriogenology, 2009, 71(4): 643-650 (doi: 10.1016/j.theriogenology.2008.09.036).

9. Taberner E., Morato R., Mogas T., Miro J. Ability of Catalonian donkey sperm to penetrate zona pellucida-free bovine oocytes matured in vitro. Anim. Reprod. Sci., 2010, 118(24): 354-361 (doi: 10.1016/j.anireprosci.2009.08.005).

10. Pérez-Garnelo S.S., Oter M., Broque C., Talavera C., Delclaux M., Martine z- Nevado E., Pa las z A.T., D e 1 a Fu e n t e J. Post-thaw viability of European Bison (Bison bonasus) semen frozen with extenders containing egg yolk or lipids of plant origin and examined with a heterologous in vitro fertilization assay. J. Zoo Wild Med., 2006, 37(2): 116-125 (doi: 10.1638/05-039.1). 
11. Ernst L.K., Abilov A.I., Sipko T.P., SHumov A.V., Sokolovskaya I.I., Ko m barova N.A., B ro nsk y a A.V. Molochnoe i myasnoe skotovodstvo, 1993, 4: 19-21 (in Russ.).

12. Cogni e Y., B aril G., Poulin N., Mermillod P. Current status of embryo technologies in sheep and goat. Theriogenology, 2003, 59(1): 171-188 (doi: 10.1016/S0093-691X(02)01270-0).

13. L o n e rga n P., F a i r T. In vitro-produced bovine embryos: dealing with the warts. Theriogenology, 2008, 69(1): 17-22 (doi: 10.1016/j.theriogenology.2007.09.007).

14. Gil M.A., Cue 11 o C., Parrilla I., Vazquez J.M., Roc a J., Martinez E.A. Advances in swine in vitro embryo production technologies. Reprod. Domest. Anim., 2010, 45: 4048 (doi: 10.1111/j.1439-0531.2010.01623.x).

15. H i n r c h s K. In vitro production of equine embryos: state of the art. Reprod. Domest. Anim., 2010, 45: 3-8 (doi: 10.1111/j.1439-0531.2010.01624.x).

16. Dang-Nguyen T.Q., Somfai T., Haraguchi S., Kikuchi K., Tajima A., $\mathrm{K}$ a n a i Y., $\mathrm{Nag}$ a i T. In vitro production of porcine embryos: current status, future perspectives and alternative applications. Anim. Sci. J., 2011, 82(3): 374-382 (doi: 10.1111/j.17400929.2011.00883.x).

17. Ow iny O.D., B a r ry D.M., Agaba c M., Godke R.A. In vitro production of cattle $\times$ buffalo hybrid embryos using cattle oocytes and African buffalo (Syncerus caffer caffer) epididymal sperm. Theriogenology, 2009, 71(6): 884-894 (doi: 10.1016/j.theriogenology.2008.10.016).

18. Z i X-D., Lu H., Y i n R-H., Che n S-W. Development of embryos after in vitro fertilization of bovine oocytes with sperm from either yaks (Bos grunniens) or cattle (Bos taurus). Anim. Reprod. Sci., 2008, 108(1-2): 208-215 (doi: 10.1016/j.anireprosci.2007.08.005).

19. Kochhar H.P.S., Appa Ra o K.B.C., Luciano A.M., Totey S.M., Gandolfi F., B a s r u r P.K., K ing W.A. In vitro production of cattle-water buffalo (Bos taurus - Bubalus bubalis) hybrid embryos. Zygote, 2002, 10(2): 155-162 (doi: 10.1017/S0967199402002216).

20. Singina G., Taradajnic T., Taradajnic N., Zinovieva N. Effects of in vitro culture system modification using CRlaa medium on embryo development and pregnancy rate in cattle. Reprod. Fertil. Dev., 2014, 26(1): 154 (doi: 10.1071/RDv26n1Ab81).

21. Parrish J.J., Susko-Parrish J.L., Leibfried-Rutledge M.L., Critser E.S., Eyestone W.H., First N.L. Bovine in vitro fertilization with frozen-thawed semen. Theriogenology, 1986, 25(4): 591-600 (doi: 10.1016/0093-691X(86)90143-3).

22. Ros e n k rans C.F.Jr., First N.L. Effect of free amino acids and vitamins on cleavage and developmental rate of bovine zygotes in vitro. J. Anim. Sci., 1994, 72(2): 434-437.

23. Krishnakumar S., Whiteside D., Dance A., Elkin B., Thundathil J. Effect of chilling duration on post-thaw characteristics of sperm from the North American bison (Bison bison). Reprod. Dom. Anim., 2013, 48(4): 636-642 (doi: 10.1111/rda.12137).

24. Chikamatsu N., Urakawa M., Fukui Y., Aoyagi Y., Ono H. In vitro fertilization and early development of bovine follicular oocytes matured in different culture systems and inseminated with spermatozoa treated by different methods. Jpn. J. Anim. Reprod., 1989, 35: $154-158$.

25. Long C.R., Pinto-Correia C., Duby R.T., Ponce de Leon F.A., Boland M.P., Roch e J.F., Robl J.M. Chromatin and microtubule morphology during the first cell cycle in bovine zygotes. Mol. Reprod. Dev., 1993, 36(1): 23-32 (doi: 10.1002/mrd.1080360105).

26. $\mathrm{S}$ i n g i n a G.N., T a rad a in i k T.E., T a ra da i n i k N.P. Problema biologii produktivnykh zhivotnykh, 2011, 4: 132-133 (in Russ.). 